\title{
Insurers and Their Multidimensional Regulatory Landscape
}

\author{
Daniel Schanté and Lucía Caudet \\ Comité Européen des Assurances, 29, square de Meeûs, BE-1000 Brussels, Belgium. \\ E-mail: caudet@brussels.cea.assur.org
}

This paper looks at all the European and international organizations that have an influence on insurance companies' regulatory environment.

The Geneva Papers (2005) 30, 19-28. doi:10.1057/palgrave.gpp.2510014

Keywords: European supervision \& regulation; international organizations; European institutions

\section{Insurers' regulatory framework: a changing landscape}

EP, ECJ, DG SANCO, CEIOPS, NFCC, IAIS, etc.-familiar with all these abbreviations? ${ }^{1}$ Well, you had better be if you wish to influence the shape of future insurance regulation! Indeed, as new bodies and international organizations have more and more influence over an insurance company's regulatory environment, learning how to deal with this landscape becomes a must. In this overview of the various legislative, regulatory, and supervisory bodies, we will focus on those relevant to insurance.

\section{The European Union}

The rough landscape

Most of us know roughly how the European Union (EU) functions. Its leading institutions are:

- the European Commission (something like a government representing general interest),

- the European Parliament (with directly elected representatives defending the concerns of our citizens) and

- the Council of the EU (with ministers representing national governments).

This balance is often exemplified by the expression "the institutional triangle".

${ }^{1}$ EP: European Parliament; ECJ: European Court of Justice; DG SANCO: European Commission Directorate General for Health and Consumer Protection; CEIOPS: Committee of European Insurance and Occupational Pensions Supervisions; NFCC: New Financial Conglomerates Committee; IAIS: International Association of Insurance Supervisors. 
Other institutions include:

- the Court of Justice of the European Communities (which ensures that EU law is complied with and that the treaties are correctly interpreted and applied, and whose rulings have on many occasions had an impact on the insurance industry such as the recent decision on the bonus/malus system),

- the European Court of Auditors (which checks that all the EU's revenue has been received and all its expenditure incurred in a lawful and regular manner and that the EU budget has been managed soundly),

- the European Ombudsman,

- the European Data Protection Supervisor.

The EU's financial bodies are:

- the European Central Bank (responsible for managing the euro and the EU's monetary policy),

- the European Investment Bank (which finances projects to help the EU's less developed regions and to help make small businesses more competitive), with its European Investment Fund.

Its advisory bodies are:

- the European Economic and Social Committee (which represents the various interest groups that collectively make up "organized civil society"),

- the Committee of the Regions (which represents regional and local governments).

When it starts getting a little more complicated - a closer look at the "institutional triangle"

\section{The European Commission}

As the EU's executive arm, the Commission is one of the EU's key institutions. It acts with complete political independence, upholding the interest of the EU as a whole. The Commission is also the only institution that has the right to propose new EU legislation. It ensures that the regulations and directives adopted by the Council and Parliament are being put into effect. It further carries out decisions taken by the EU Council and is largely responsible for managing the EU's common policies and their budget. It is answerable to Parliament, and the entire Commission has to resign if Parliament passes a motion of censure against it, which occurred for the first time in 1999 under the Jacques Santer mandate.

Members of the Commission are appointed for a 5-year period by agreement between the Member States, subject to approval by Parliament. During their mandate, they cannot take instructions from any Member State government. Since 1 November 2004, the new Commission has only 25 members - one per country, regardless of its size and population.

The Commission is assisted by a civil service made up of more than 30 "Directorates General" (DGs) and services, based mainly in Brussels and Luxembourg. Unlike the secretariats of traditional international organizations, the Commission has its own financial resources and can thus act quite independently. European insurers are 
principally concerned with DG Internal Market. However, a number of relevant initiatives such as the gender equality directive or the environmental liability directive emanated from other Directorates General. Indeed, insurers are also concerned with the DGs in charge of Competition, Taxation \& Customs, Health \& Consumer Protection, Employment \& Social Affairs, Environment, Agriculture \& Rural Development, Transport \& Energy, Entreprise \& Information Society, and Trade. This means that the insurance sector is not always influenced by insurance experts and that our positions need to be communicated to a multitude of players with different backgrounds.

\section{The European Parliament}

The European Parliament represents the EU's citizens and shares legislative power with the EU Council. They do so using three different procedures on top of simple "consultation":

- the "cooperation procedure", under which Parliament gives its opinion on draft directives and regulations proposed by the European Commission, which can amend its proposal to take account of Parliament's opinion,

- the "assent procedure", under which Parliament must give its assent to international agreements negotiated by the Commission, to any proposed enlargement of the EU and to a number of other matters including any changes in election rules,

- the "co-decision procedure", where the Parliament is on an equal footing with the Council. The procedure applies to legislation related to a series of important issues including the free movement of workers, education, research, the environment, Trans-European Networks, health, culture, consumer protection and the internal market. Parliament has the power to throw out proposed legislation in these fields if an absolute majority of Members of the European Parliament (MEPs) vote against the Council's common position. However, the matter can be put before a conciliation committee. The co-decision procedure is nowadays the most frequent procedure in the area of insurance legislation. The generalization of this procedure represents a great victory for the European Parliament, which has seen its powers decisively strengthened over the past decades. For professional federations such as Comité Européen des Assurances (CEA), the many steps and players involved in the procedure imply a high degree of work but they also multiply the chances of getting our position across.

Parliament and the Council also share equal responsibility for adopting the EU budget. MEPs are directly elected, by universal suffrage, every 5 years. Until the 2004 elections there were 626 MEPs. Since enlargement and until 2007, the number will grow to 732 . It will then rise to 786 by 2009 , when the next EP elections will be held. The distribution of the number of seats per Member State is proportional to their population.

The Secretariat General is based in Luxembourg. The EP normally holds its plenary session in Strasbourg and any additional sessions in Brussels. Just as in the European Commission, work is carried out within a number of "departments". The EP has 17 
committees that do the preparatory work for its plenary sessions. Among these committees, the most relevant to insurance are those for Citizens' Freedoms and Rights, Justice \& Home Affairs, for Economic \& Monetary Affairs, for Employment \& Social Affairs, for Environment, for Industry, External Trade, Research \& Energy, and for Legal Affairs.

Parliamentary debates are dominated by the political groups to which MEPs are affiliated. Since the 2004 elections, the main political groups are the Christian Democrats and European Democrats (EPP-ED group), followed by the Socialists (PES group), the Liberals (ALDE Group), and the Greens (Greens/EFA group).

\section{The Council of the EU}

The Council of the EU or Council of Ministers is the EU's main decision-making institution. Every Council meeting is attended by one minister from each of the Member States. Its composition varies; that is, which ministers attend a meeting depends on which topic is on the agenda. There are nine different Council "configurations" covering all the different policy areas (foreign policy, agriculture, industry, transport, environment, finance, etc.). The Economics \& Finance Council is, of course, of particular relevance to insurers. The Council's work as a whole is planned and coordinated by the General Affairs and External Relations Council.

The preparatory work for Council meetings is done by the Permanent Representatives Committee (Coreper), made up of the Member States' ambassadors to the EU, assisted by officials from the national ministries. The Council's administrative work is handled by its General Secretariat, based in Brussels.

On important questions such as amending the treaties, launching a new common policy or allowing a new country to join the Union, and also on the recent gender equality directive based on Article 13 of the treaty, the Council has to agree unanimously. Unanimity has proved difficult to reach in a number of areas in the past. It remains to be seen how the enlarged EU will manage this difficulty.

In most other cases, qualified majority voting is required; that is, a decision cannot pass without a specified minimum number of favourable votes. As of 1 November 2004, the number of total votes is 321 (the number of votes per EU country roughly reflects the size of its population). A minimum of 232 votes ( 72.3 per cent) is required to reach a qualified majority. In addition,

- a majority of Member States (in some cases two-thirds) must approve the decision, and

- any Member State can ask for confirmation that the votes cast in favour represent at least 62 per cent of the EU's total population.

Each EU country in turn presides over the next Council for a 6-month period. The next Presidencies will be held by Luxembourg (January-June 2005), United Kingdom (July-December 2005), Austria (January-June 2006), and Finland (July-December 2006).

The Presidency is also linked to the meetings of the European Council, not to be confused with the Council of the EU. The European Council brings together the presidents and prime ministers of all the EU countries plus the Presidents of the 
Table 1 The four levels of the comitology procedure

\begin{tabular}{|c|c|}
\hline 1: & egulation by EU institutions. \\
\hline & $\begin{array}{l}\text { Development of technical implementation measures by the regulators meeting in the European } \\
\text { Insurance and Occupational Pensions Committee (EIOPC) after consultation with the Level } 3 \\
\text { Committee of European Insurance and Occupational Pensions Supervisors (CEIOPS), } \\
\text { structured into working groups. }\end{array}$ \\
\hline Level 3 & $\begin{array}{l}\text { CEIOPS works on interpretation, recommendations and guidelines to ensure consistent } \\
\text { implementation and application. }\end{array}$ \\
\hline & Member States' implementation and compliance monitored by the Commission. \\
\hline
\end{tabular}

European Commission and of the European Parliament. It meets, in principle, four times a year, and is chaired by the president or prime minister of the country currently presiding over the Council of the EU. Some of the issues they debate such as foreign policy can be highly contentious.

\section{And then came Baron Lamfalussy...}

Knowing the procedures, rules, and political balances behind European regulation is not easy - but it is CEA's daily work. However, CEA's working environment is changing radically, compelling the industry to adapt rapidly and effectively.

Fast-changing financial market developments bring with them the need for a new, more flexible and efficient framework for the design and implementation of EU legislation. That is what the Committee of Wise Men on the Regulation of European Securities Markets, chaired by Baron Alexandre Lamfalussy, had in mind when it designed the four-level comitology procedure (see Table 1). At the end of 2002, the EU decided to apply the comitology procedure to all financial services including insurance with the objective of dealing more effectively with financial developments.

The principle of this procedure is that the EU institutions design the main principles of financial services legislation while the more technical details are dealt with by specialized, sectoral committees.

European insurers have welcomed this decision. However, they have also warned that speed should not adversely affect the quality of legislation or compromise legal certainty.

As Baron Lamfalussy put it, "consultation and transparency are essential preconditions for the successful extension of the comitology procedure to banking and insurance. But this will require the industry as well as regulators and supervisors to commit a considerable amount of skills, resources and time". The CEA has, on many occasions, emphasized the need for the permanent consultation and participation of the insurance industry at every level of the procedure. Clear definitions and distinctions between the different levels of the procedure and absolute transparency are also essential.

Transparency, coherence and consultation will be essential within the future comitology procedure. But these principles should also apply to other regulatory bodies. 


\section{Other European bodies with an impact on insurance}

\section{The New Financial Conglomerates Committee}

The New Financial Conglomerates Committee (NFCC) gathers Member State finance ministries and usually one supervisor per Member State. Secretariat and Chair are provided by the European Commission Internal Market Directorate General.

The NFCC focuses its work on the Financial Conglomerates Directive and its requirements, that is, mainly prudential requirements on holding level in conglomerates.

\section{The Financial Services Committee}

The Financial Services Committee (FSC) is a highly influential advisory committee to the Council of the EU, composed of high-level representatives from the Member States and the European Commission. The European Central Bank and relevant committees of regulators have observer status.

With growing influence on new regulatory initiatives in the financial services sector, the FSC provides for cross-sectoral reflection beyond the legislative process (on the strategy for financial services issues, the progress and implementation of regulation, political advice and oversight, etc.).

\section{The Accounting Regulatory Committee}

The Accounting Regulatory Committee (ARC) is composed of representatives from Member States (mainly ministries and central banks) and chaired by the Commission. The European Central Bank, Committee of European Securities Regulators (CESR), the Banking Advisory Committee and the Insurance Committee are among the observers on the ARC.

The ARC provides the European Commission with its decision on whether an accounting standard should or should not be endorsed (adopted) after having received the official opinion of the European Financial Reporting Advisory Group (EFRAG).

\section{The European Financial Reporting Advisory Group}

The EFRAG was created by all parties involved in financial reporting in Europe, as a private sector initiative. CEA is one of the founding members of EFRAG. The aim of EFRAG is to give a proactive contribution to the work of the International Accounting Standards Board (IASB). EFRAG advises on the technical assessment of the IASB standards and interpretations for application in Europe.

The EFRAG has a two-tier level: a Technical Expert Group to carry out the technical work and a Supervisory Board of Organizations to guarantee representation of interests and enhance legitimacy. EFRAG operates independently of these organizations.

\section{The Economic and Financial Committee}

The Economic and Financial Committee (EFC) is an advisory body for preparing the work of the Council, by keeping under review, among other things, the economic and 
financial situation, the euro exchange rate, and relations with third countries and international institutions. It provides the framework within which the dialogue between the Council and the European Central Bank (ECB) is prepared and takes place.

The EFC works in two formations: a restricted one, where only members from national administrations, the Commission and the ECB participate, and the full one where all members, including the members from national central banks, take part.

\section{The international scene}

With EU institutions, committees, consultative bodies, international regulators and supervisors etc, new regulations are being influenced by even more policymakers than ever, both at EU and global level.

At the latter level, European insurers face a number of international issues including World Trade Organization (WTO) negotiations for improved market access, U.S. requirements for foreign reinsurers, supervisory standards set by the International Association for Insurance Supervisors (IAIS), and the Organization for Economic Cooperation and Development (OECD) recommendations. And everything points towards an increased role for these international organizations in shaping the environment of the insurance industry.

\section{The Organization for Economic Cooperation and Development}

The OECD groups 30 member countries sharing a commitment to democratic government and the market economy. Known for its publications and its statistics, the organization covers economic and social issues from macroeconomics to trade, education, development, science and innovation.

Its Insurance Committee meets twice a year and brings together representatives from the member countries' ministries and supervisory authorities, as well as representatives from the private sector. Representatives of a number of other international organizations, for example, the WTO, the Commission of the European Communities, CEA and the IAIS also take an active part in the work of the Committee. CEA is an active member of the OECD's Terrorism Task Force.

The Insurance Committee's mission is to develop international cooperation in the insurance field with a view to improving the functioning of insurance markets and encouraging countries to adopt policies for promoting international trade in insurance.

\section{The International Association of Insurance Supervisors}

The IAIS represents about 100 insurance supervisory authorities all around the globe. More than 70 observers represent industry associations, professional associations, insurance and reinsurance companies, consultants, and international financial institutions. CEA has observer status with the right to comment.

The IAIS issues global insurance principles, standards and guidance papers, provides training and support on issues related to insurance supervision and organizes 
meetings and seminars for insurance supervisors. The IAIS works closely with other financial sector standard-setting bodies and international organizations working to promote financial stability. It has a major input on issues related to reinsurance, solvency rules, transparency and disclosure requirements, corporate governance, accounting and money laundering.

\section{The World Trade Organization}

One of the youngest of the international organizations, the WTO is the successor to the General Agreement on Tariffs and Trade (GATT), established in the wake of the Second World War. GATT and the WTO have helped to create a strong and prosperous worldwide trading system contributing to unprecedented growth. The system was developed through a series of trade negotiations, or rounds, held under GATT. The first rounds dealt mainly with tariff reductions but later negotiations included other areas such as anti-dumping and non-tariff measures.

The Doha Development Agenda (DDA), launched at the fourth WTO Ministerial Conference in November 2001, has added work on non-agricultural tariffs, trade and environment, anti-dumping and subsidies, investment, competition policy, transparency in government procurement, intellectual property, and a range of issues raised by developing countries. The deadline for submitting revised offers has been scheduled for May 2005. The WTO has nearly 150 members, accounting for over 97 per cent of world trade. Around 30 others are negotiating membership.

\section{The European Services Forum}

The European Services Forum (ESF) is a network of representatives from the European services sector committed to promoting actively the interests of European services and the liberalization of services markets throughout the world in connection with the General Agreement on Trade in Services (GATS) 2000 negotiations.

The European Services Forum comprises more than 40 major European service companies, represented by their CEOs in the European Service Leaders Group, and more than 40 European service federations representing more than 20 services sectors. ESF represents the very large majority of the European service industries that have a direct interest in supplying international services.

\section{The International Accounting Standards Board}

The IASB is an independent, privately funded accounting standard-setter based in London. Board members come from nine countries. The IASB aims at developing a single set of high-quality understandable and enforceable global accounting standards that require transparent and comparable information in general-purpose financial statements. The Board cooperates with national accounting standard-setters to achieve convergence in accounting standards around the world. Once endorsed by the EU, IASB standards will apply to the consolidated accounts of all EU-listed companies as of 1 January 2005. 
The IASB structure is designed to support the legitimacy of a standard-setting organization. Members include the Trustees, the International Financial Reporting Interpretations Committee (IFRIC), and the Standards Advisory Council.

\section{The World Bank}

The World Bank aims to fight poverty and improve living standards in the developing world. It provides loans, policy advice, technical assistance and knowledge-sharing services to low- and middle-income countries.

The World Bank's efforts contributed to the adoption of the EU Financial Services Action Plan (FSAP) in May 1999, the aim of which is to increase the integration and competitiveness of the EU's financial markets.

\section{The National Conference of Insurance Legislators and the National Association of Insurance Commissioners}

The United States National Conference of Insurance Legislators (NCOIL) is an organization of state legislators primarily concerned with insurance. Its purpose is to help legislators make informed decisions on insurance issues that affect their constituents and to declare opposition to federal encroachment of state authority in regulating the business of insurance.

The U.S. National Association of Insurance Commissioners (NAIC) is an organization of state insurance regulators. It provides a forum for the development of uniform policy when uniformity is appropriate, helps regulators to protect the interests of insurance consumers, and addresses the need to coordinate regulation of multistate insurers.

Both NCOIL and NAIC are involved in the ongoing discussions on the reduction of collateral requirements for non-U.S. reinsurers.

\section{How not to get lost and influence insurance regulation effectively}

Although only a brief summary is presented here of the role of the major bodies involved in shaping insurers' regulatory environment, it provides an idea of the broader picture.

This new landscape compels us all to redouble our efforts. Presenting the right message at the right moment and to the right person in the policy-making process is now more crucial than ever. Changes in our regulatory environment compel the insurance sector to adapt to new structures and come into contact with new decision makers, while simultaneously monitoring an increasing number of organizations and reacting to uncountable proposals.

The insurance industry's lobbying strategy needs to be more coordinated than ever, and CEA is a valuable tool enabling European insurers to reach out to decision makers adequately. Through CEA, European insurers have a window of opportunity to shape their future regulatory framework efficiently. 


\section{About the Authors}

Mr Daniel Schanté was appointed Director General of the Comite Européen des Assurances (CEA) in May 2001. From 1984 to 2001, he held various executive posts in European insurance and bancassurance groups. Before joining CEA, he was a member of the board of Winterthur-Europe and advisor to the Chief Executive Officer of Credit Suisse Winterthur (Credit Suisse Group). He began his professional career in 1974 as a sales engineer in the IT sector. Two years later, he became a consultant with McKinsey \& Company, where he specialized in financial services and was active in Germany, the Netherlands and France. Born in 1950, Daniel Schanté graduated from the École Polytechnique (Paris) in 1974. He went on to study at the Stanford Business School (USA), earning a Masters in Business Administration in 1978. Daniel Schanté is a member of the Honors Committee of the International Insurance Society.

Lucia Caudet was born in Los Angeles in 1976, and has double Spanish/German nationality. After obtaining both Spanish and German school degrees, she graduated in Law from Madrid's Universidad Autónoma and then took a masters in European Law at the Institut d'Etudes Européennes in Brussels. In 2000, she joined the Union of European Federalists (UEF), where she managed the organization's campaign activities and coordinated the meetings and work programme of the European Parliament European Constitution Intergroup. Lucía joined CEA in June 2002, where she advises the organization on its communication strategy and manages media relations, publications and newsletters, conferences and events, as well as CEA's website. She also coordinates member associations' communication through a Communications \& PR Committee. 